\title{
Restoration tailings and recultivation of soil fertility
}

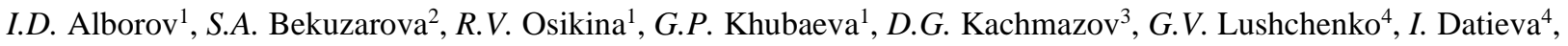 \\ and $M$. Dzampaeva ${ }^{2}$ \\ ${ }^{1}$ North-Caucasian Mining and Metallurgical Institute, 362021 Vladikavkaz, Republic of North Ossetia-Alania, Russia \\ ${ }^{2}$ Gorsky State Agrarian University, 362040 Vladikavkaz, Republic of North Ossetia-Alania, Russia \\ ${ }^{3}$ South Ossetian State University, 100001 Tskhinval, Republic of South Ossetia, Russia \\ ${ }^{4}$ North Caucasus Research Institute of Mountain and Piedmont Agriculture of the Vladikavkaz Scientific Center of the Russian Academy \\ of Sciences, 363110 Mikhailovsky Village, Republic of North Ossetia-Alania, Russia
}

\begin{abstract}
In the mining industry place, tailing dumps remain, which contain toxic substances. For their rehabilitation, it is proposed to use local zeolite-containing clays of North and South Ossetia Eredvit and Dialbekulit containing a complex of minerals with an alkaline reaction of the environment. In addition to clays, peat with a high content of humic substances is introduced into the substrate. The prepared substrate is irrigated with mineral sulfur-containing water of the Tamisk spring. Accumulating toxic substances and herbs are sown on the surface of the densified area: annual and perennial herbs, for example, amaranth, legumes, winter camelina. Before sowing, grass seeds are mixed with the husk of winter camelina. Such remediation of contaminated sites reduces the toxicity of tailings to $90 \%$ and restores soil fertility.
\end{abstract}

\section{Introduction}

In the areas where mining and processing enterprises are located, one of the primary sources of disturbance and pollution of various components of the natural environment is the storage of solid mineral waste. In the Russian Federation, the total mass of solid mineral waste exceeds 20 billion tons. So far, the dominant method of handling waste from the mineral resource complex is land storage. This process leads to the occurrence of adverse environmental situations in areas of more than 4 million hectares. So, these areas are characterized by deterioration of the sanitary-hygienic situation, violation, and modification of natural landscapes, as well as the loss of natural resources $[1,2,14,15]$.

One of the pressing environmental problems of the Russian Federation is the violation of the state of the environment during the development of mineral deposits. The mining industry leads to the destruction of soil and vegetation. Desert and barren technogenic landscapes are formed. The destructive consequences of mining are manifested in the form of disturbances and pollution of all elements of the biosphere: water and air, soil, flora, and fauna.

The most harmful is dusty rock dumps containing toxic metals in the dust. $\mathrm{Cu}, \mathrm{Zn}, \mathrm{Pb}, \mathrm{Ce}, \mathrm{N} 1$, and other chemical elements and chemical compounds cause poisoning of the atmosphere and destruction of living organisms [3, 4, 11-13].

According to the socio-economic development strategy of Russia, the goal is insurance of the country's economic security. This goal is associated with the need to significantly improve the efficiency of domestic production, the competitiveness of manufactured products.

Therefore, the issues solution of the environment necessary preservation for the normal functioning of the environment is one of the urgent problems. In this regard, it is necessary to research to reduce the growing harmful technological load on nature. At the stage of raw material extraction, substandard raw materials are sent to tailings, which occupy significant land areas, causing industrial pollution.

Of the most significant environmental factors are studies aimed at the restoration of contaminated sites with toxic substances. This factor determines the favorable existence of bio objects in the territory inhabited by them. One of the most problematic objects is tailings, containing many harmful substances (heavy metals, radionuclides).

In the republics of North Ossetia-Alania and South Ossetia, enrichment plants tailings are located in the valleys of the Fiagdon and Ardon rivers, as well as in the Kvaysa region. In the valleys of these territories are tourist routes and resort areas. Wind erosion and the transfer of large masses along valleys are characteristic of these territories, which has a depressing effect on living organisms [1-6]. Reclamation of these sites and the creation of favorable conditions for vacationers is the main direction of the presented research.

Many measures are aimed at reducing erosion processes for the rehabilitation of sloping lands and restoration of soil fertility. For this purpose, moistureabsorbent bentonite crushed clay is introduced into the soil; perennial grasses and fertilizers are sown in a mixture with humates [7]. 
However, the added clay, fertilizer, and humate, crushed to a powder, are costly. Only perennial grasses sown in the first year develop poorly and are susceptible to wind erosion, especially under challenging conditions.

Some studies are aimed at restoring disturbed lands, which are carried out in 2 stages. The first stage of reclamation is associated with the creation of insulating drainage from rock, gravel, gravel, followed by the application of a layer of the substrate from river sand, soil, sawdust, granulated slag, coal powder, peat, cake with mixing all the ingredients and rolling them. In the second stage, biological reclamation is carried out by sowing vegetation in a mixture with mineral fertilizers [8].

The applied technological processes have low efficiency. Standard technologies involve the implementation of a rather time-consuming process, consisting of several techniques. One of the technological methods is the preparation of an aqueous solution of polyvinyl alcohol and applying it to the surface of the soil.

Moisture sorbent is preliminarily introduced into the soil, using bentonite clay powder as the base. Additionally, seeds of perennial grasses are sown in the surface layer of the soil, fertilizers, and humates are added in the form of a mixture with bentonite clay powder [9].

In this study, as a rational approach, a method for the rehabilitation of tailings is proposed, which includes two stages: technical and biological. At the first stage, geosynthetic material is laid, an artificially created substrate made of fertile soil. At the second stage, grass mixtures of lower grasses are sown, and natural wood mulch is introduced [10].

Sown grassroots are considered soil-tolerant. However, in the presence of water erosion, they are washed off on sloping lands, not reaching full development. Besides, these grassroots cereals do not have sorption and accumulating properties to absorb toxic substances located in the upper layer of tailings. These processes reduce the effectiveness of traditional remediation methods.

The purpose of this research work is to develop an economically and environmentally friendly method for the rehabilitation of tailings and restoration of disturbed lands.

\section{Research methods}

The tailings site is covered with a substrate of zeolitecontaining clay and peat of local origin in a ratio of $1: 2$, modified with hydrogen sulfide mineral water, and after tamping, the seeds of the plant are sown. Amaranth seeds, annual and perennial leguminous grasses, winter camelina, are sown. A particular concern of these plants is their accumulative ability to absorb toxic substances from the soil. Before sowing, the seeds of these crops are mixed with the waste husks of winter camelina.

Natural agro-ore of North and South Ossetia contains many elements that improve soil fertility. They include silicon, iron, calcium, manganese, potassium, sodium, phosphorus, sulfur, copper, and zinc. Due to the high calcium content (more than $30 \%$ ), the reaction of zeolite-containing clays is alkaline $(\mathrm{pH} 8.1)$. The first source of clay Eredvit is located at an altitude of $1000 \mathrm{~m}$ above sea level in South Ossetia.

Another clay source, Dialbekulit, is located at the same height in the floodplain of the Ursdon River in North Ossetia. Both types of these clays have a high sorption ability - peat of the same places, saturated with moisture up to $85 \%$. In a mixture with clays, it has a thermal conductivity $(0.37 \%)$ and compressive strength of $140 \mathrm{~kg} / \mathrm{cm}^{2}$.

Clay Eredvit and Dialbekulit take 2 tons each, mix with peat, covering the surface of the tailings area of 2.5 hectares, followed by irrigation with hydrogen sulfide water of the Tamisk spring in an amount of 400 liters. Then the treated area is rolled. The husk of winter camelina plants is crushed and mixed with plant seeds accumulators.

At the same time, our research was aimed at the rehabilitation of contaminated soils with the help of plants with sorption ability. These are plants: amaranth, legumes and their crop residues, legumes, ragweed, stevia, corn cobs, sunflower baskets, oilseeds (camelina, guizotia, crambe, and other plants).

Along with plants for soil remediation, zeolitecontaining clays of local origin (mountains and foothills of the North Caucasus), as well as biological fertilizers, providing restoration of disturbed lands, were introduced.

The experiments were carried out at the experimental sites of the Gorsky State Agrarian University, the Geophysical Institute and the North Caucasus Research Institute of Mining and Piedmont Agriculture of the Vladikavkaz Scientific Center of the Russian Academy of Sciences, North Ossetian State University named after K.L. Khetagurov, Comprehensive Research Institute of the Russian Academy of Sciences named after H.I. Berbekov (Grozny).

\section{Results}

An enriched plot with organic substances significantly reduces toxicity and restores a fat layer suitable for cultivating crops. Moreover, the restoration of contaminated sites was carried out based on recycled waste bards and corn cobs, mixing them with local natural zeolite-containing clays. By adding corn cobs to the clay substrate, the aeration of the area and its filtration are improved. The results of the experiment are summarized in table 1 .

Therefore, a technology for improving soils is possible without high costs and, very importantly, with the simultaneous disposal of crop products and alcohol industry.

The advanced technology consists of mixing natural zeolite-containing clays with corn cobs crushed in a postalcohol bard. As studies show, this technology allows rehabilitating land disturbed by mining operations, reduce the number of heavy metals and soil acidity $(\mathrm{Ph})$. 
After threshing the seeds of winter camelina, its husk remains, which contains a sufficient amount of phosphorus (3-4\%), flavonoids, rutin $(0.6-07 \%)$. These substances have stimulating properties and protective features against pathogens and various stresses.

The use of winter camelina in technology creates favorable conditions for the development of sown seeds. When mixing all components of clay and peat, Tamisk saturated mineral water is used. This water can reduce the elements of mercury and arsenic present in the tailings.
The technology assumes that after compaction of the mixture, clay, and peat, containing more than $40 \%$ of humic substances, the substrate is saturated with mineral hydrogen sulfide water of the Tamisk spring, which includes about $100 \mathrm{mg} / \mathrm{dm}^{3}$.

Seeds are sown in the year the tailings are treated - in August. This period allows providing a growing green mass of plants next year, which reduces the toxicity of the disturbed area. The research results are presented in Table 2 .

Table 1. Reducing the content of heavy metals

\begin{tabular}{|c|c|c|c|c|c|c|}
\hline \multirow[t]{2}{*}{ Experience Options } & \multicolumn{6}{|c|}{$\begin{array}{l}\text { Contents of heavy metals in the soil, } \\
\mathrm{mg} / \mathrm{l}\end{array}$} \\
\hline & $\mathrm{Pb}$ & $\mathrm{Zn}$ & $\mathrm{Cu}$ & $\mathrm{Cd}$ & $\mathrm{Fe}$ & $\mathrm{P}_{\mathrm{h}}$ \\
\hline $\begin{array}{l}\text { Control soils } \\
\text { (no improvement) }\end{array}$ & 12.9 & 136.0 & 78.0 & 0.64 & 28.0 & 4.2 \\
\hline Alanite coatings & 8.6 & $8 . .0$ & 39.0 & 0.52 & 22.0 & 5.4 \\
\hline Corn stumps + alcohol bard & 5.6 & 39.0 & 21.0 & 0.34 & 16.0 & 5.9 \\
\hline Cresting + Alanite Layer & 2.1 & 14.0 & 13.6 & 0.22 & 9.6 & 6.2 \\
\hline $\begin{array}{l}\text { Clay dialbeculite }+ \text { corn cobs }+ \text { alcohol bard }+ \\
\text { sowing perennial herbs }\end{array}$ & 0.2 & 8.0 & 9.2 & 0.01 & 4.5 & 6.8 \\
\hline
\end{tabular}

Table 2. Reduction of the content of toxic elements in the tailings pond $(\mathrm{mg} / \mathrm{kg})$

\begin{tabular}{|l|c|c|c|c|}
\hline \multicolumn{1}{|c|}{ Experience option } & $\mathrm{Sb}$ & $\mathrm{Cd}$ & $\mathrm{Ni}$ & $\mathrm{Zn}$ \\
\hline $\begin{array}{l}\text { Soil before reclamation } \\
\text { (the control) }\end{array}$ & 689.2 & 14.4 & 42.7 & 452.6 \\
\hline Overlay of a substrate of 2 types of clay & 404.6 & 13.1 & 38.4 & 381.0 \\
\hline Substrate 2 clay + peat & 312.4 & 10.1 & 28.2 & 335.5 \\
\hline Substrate + hydrogen sulfide water & 262.6 & 6.28 & 14.7 & 328.0 \\
\hline Substrate + hydrogen sulfide water + storage plants & 178.4 & 1.8 & 12.6 & 125.0 \\
\hline $\begin{array}{l}\text { Substrate + peat + mineral hydrogen sulfide water + } \\
\text { sowing of accumulating cultures mixed with a husk of } \\
\text { winter camelina }\end{array}$ & 56.8 & 0.38 & 4.0 & 82.0 \\
\hline $\begin{array}{l}\text { Reduction in soil toxicity, \% } \\
\text { Reduch }\end{array}$ & 91.8 & 87.5 & 90.5 & 98.2 \\
\hline
\end{tabular}

\section{Conclusion}

Based on the obtained experimental results, it can be concluded that the use of local sorbing sources of raw materials can significantly reduce the toxicity of tailings and restore soil fertility in one season.

Moreover, the achieved effect can be obtained from natural sources of local origin. In the proposed technology for soil restoration, plant species and crops with maximum bioindication capabilities are used. Plants are selected based on comparing the sorption abilities of different plants in the same development phases but in different environmental conditions.
Accumulative plants such as amaranth, legumes, and other plants improve toxic soils. The results of the study show that it is possible to reduce the toxicity of soils and restore their fertility significantly. In the process of industrial plant waste mixed with zeolite-containing clays, it is possible to reduce the infected areas of soil, acidity, and restore soil fertility.

\section{References}

1. B.A. Simkin, B.Ts. Bebchuk, A.V. Khokhryakov, Assessment of the consequences of the industrial 
impact of mining on the environment, Mining J., $\mathbf{5}$, 52-54 (1989)

2. G.V. Kalabin, Mining complex and environmental technologies, Mountain J., 2, 12-16 (2005)

3. N.V. Lukyanov, A.V. Myaskov, The influence of the mining industry on specially protected natural territories, Mining Inform. and Analyt. Bull. (sci. and techn. J.), 6, 323-340 (2007)

4. V.V. Kolomeychenko, A.I. Petelko, A.I. Krupchatnikov, Rational use of land (Eagle, 2000)

5. M.A. Pashkevich, Man-made arrays and their environmental impact, monograph (St. Petersburg Mining Institute, St. Petersburg, 2001)

6. N. Diaby, P. Rossi, B. Dold, C. Holliger, Microbial community evolution in a marine shore porphyry tailings deposit throughout wetland remediation (Gothenburg, 2009)

7. V.V. Medko, V.G. Cheverev, A method of protecting soils from erosion, the invention. Patent no. 2267514, published January 10, 2006. IPC S09K17/40 ().

8. A method for the rehabilitation of tailings in the conditions of Subartica, the invention. Patent no. 2571346, published December 20, 2017. Bull. no. 35. IPC V09C1/00-A01V79/02.

9. A.Kh. Sariev, V.M. Zelensky, N.Yu. Terentyev, N.N. Ochikolova, O.N. Slepova, A.A. Keyser,
A method for the rehabilitation of tailings, the invention. Patent no. 2643038, Published on January 30. 2018. Bull. no. 4. IPC A01B7 /02

10. S. Koptsik, N. Berezina, S. Livantsova, Effects of natural-soil acidification on biodiversity in boreal forest ecosystems, Water, Air, and Soil Pollut., 130, 929-934 (2001)

11. V.G. Malkovetz, L.A. Taylor, W.O. Griffin et al., Cratonic conditions beneath Arkhangelsk, Russia: Garnet Peridotites from the Gribkimberlite, in 8th Int. Kimberlite Conf., 101 (Victoria, Sun, Canada, June 22-27, 2003)

12. L.I. Sablukova, S.M. Sablukov, E.M. Verichev, N.N. Golovin, Mantle xenoliths of the Grib Pipe, Zimny Bereg area, Russia, in 8th Int. Kimberlite Conf., 107-108 (Victoria, Sun, Canada, June 22-27, 2003)

13. E.M. Verichev, V.V. Verzhak, V.K. Garanin et al., Mineralogy of diamond from the deposits of the Arkhangelsk kimberlite province (Russia), in Proc. of the 2nd South African Kimberlite Conf., 20-24 (Brazilia, Brazil, 2005)

14. I.Ya. Pigorev, Ecology of technogenic landscapes of KMA and their biological development, monograph (KSAA, Kursk, 2006)

15. A.I. Golovanov, F.M. Zimin, V.I. Smetanin, Reclamation of disturbed lands (Moscow, 2009) 